\title{
Effects of Short Term Administration of Genistein on Hypothalamic and Anterior Pituitary Hormones in Ovariectomized Gilts
}

\author{
Jeffrey Clapper*, Carolyn Paulson \\ Department of Animal Science, South Dakota State University, Brookings, USA \\ Email: Jeffrey.Clapper@sdstate.edu
}

Received 5 March 2015; accepted 3 April 2015; published 7 April 2015

Copyright $(02015$ by authors and Scientific Research Publishing Inc.

This work is licensed under the Creative Commons Attribution International License (CC BY). http://creativecommons.org/licenses/by/4.0/

\section{c) (i) Open Access}

\begin{abstract}
Administration of genistein to barrows increased anterior pituitary (AP) concentrations of IGF-I and LH and increased expression of AP IGF receptor. Whether similar changes occur in gilts remains to be determined. The objective of this experiment was to determine if short term administration of genistein increased expression of components of the AP IGF system and hypothalamic hormones and receptors involved in gonadotropin synthesis and/or release in the gilt. Sixteen crossbred gilts of similar weight $(97.7 \mathrm{~kg})$ were ovariectomized and assigned to either control (C; $\mathbf{n}=8$ ) or genistein ( $G ; n=8$ ) groups. Genistein pigs received $800 \mathrm{mg}$ of genistein in DMSO while $C$ pigs received an equal volume of DMSO i.m. on day $0,1,2$, and 3 . Blood samples were obtained on day $0,1,2$, and 3 . Pigs were slaughtered on $d 4$ when blood, AP, and medial basal hypothalami $(\mathrm{MBH})$ were collected. No difference was detected $(P>0.05)$ in AP concentrations of IGF-I or serum concentrations of IGF-I in $C$ and $G$ pigs. Anterior pituitary concentrations of LH were greater $(P<$ $0.05)$ in $G$ pigs compared with $C$ pigs. Relative expression of AP IGF-I was greater $(P<0.05)$ in $G$ pigs than C pigs. Relative expression of AP IGF-IR, IGFBP-2 and IGFBP-3 did not differ $(P>0.05)$ in $C$ and $G$ pigs. Relative expression of AP IGFBP-5 and GnRHR was increased $(P<0.05)$ in $G$ pigs compared with $C$ pigs. Relative expression of AP LH $\beta$ did not differ between $C$ and $G$ pigs. Relative expression of MBH kisspeptin was greater $(P<0.01)$ in $G$ pigs than $C$ pigs. These data provided evidence that short term administration of genistein increased expression of hypothalamic and hypophyseal hormones in gilts which could influence subsequent reproduction.
\end{abstract}

\section{Keywords}

Genistein, Gilt, LH, GnRH, Kisspeptin

\footnotetext{
${ }^{*}$ Corresponding author.
}

How to cite this paper: Clapper, J. and Paulson, C. (2015) Effects of Short Term Administration of Genistein on Hypothalamic and Anterior Pituitary Hormones in Ovariectomized Gilts. Open Journal of Animal Sciences, 5, 163-173. 


\section{Introduction}

Phytoestrogens are plant substances similar in chemical structure to estradiol. Phytoestrogens can be chemically divided into three categories, namely, flavonoids, coumestans and lignans [1]. Contained within the flavonoid group are isoflavones, such as genistein. Genistein is structurally similar to estradiol and has the ability to bind to estrogen receptors $\alpha$ and $\beta$ causing an estrogenic effect [1]. Genistein binds to the estrogen receptor (ER) $\beta$ with greater affinity than the ER $\alpha$ and can compete with other estrogens such as estrone, estradiol, and diethylstilbesterol for binding to the estrogen receptor [1]. Although the estrogenic potency of genistein is much less than that of estradiol-17 $\beta$, it has been shown to be mitogenic in breast tumors [1] and to stimulate MCF-7 tumor cell growth [2] similar to that of estradiol-17 $\beta$.

Genistein has been shown to have effects on different reproductive processes in pigs. When ovariectomized gilts were injected intramuscularly with genistein for $15 \mathrm{~d}$, their uterine and cervical mass increased, and there was enhanced expression of proliferating cell nuclear antigen in the reproductive tract, suggesting increased cell division [3]. Other investigators demonstrated that IGF-I and estrogen output increased in cultured porcine granulosa cells treated with genistein [4].

Previous research in our laboratory has demonstrated genistein's effects on the anterior pituitary gland in barrows. Intramuscular administration of $400 \mathrm{mg}$ of genistein to barrows for $16 \mathrm{~d}$ resulted in an increase in anterior pituitary gland concentrations of IGF-I and LH, and increased expression of components of the AP IGF system [5], all of which could lead to increased secretion of LH [6] [7]. To our knowledge, investigations of genistein's effects on the AP and hypothalamus in the prepubertal gilt are lacking.

Therefore, the objective of this experiment was to determine if administration of $800 \mathrm{mg}$ genistein to ovariecotmized gilts for $4 \mathrm{~d}$ increased expression of components of the AP IGF system and hypothalamic hormones and receptors known to be involved in gonadotropin synthesis and/or release.

\section{Materials and Methods}

\subsection{Animals and Procedures}

Sixteen crossbred gilts of similar age $(150 \mathrm{~d})$ and weight $(97.7 \mathrm{~kg})$ were ovariectomized and stratified into one of two treatment groups ( $\mathrm{n}=8$ /group): control (C) and $800 \mathrm{mg}$ genistein $(\mathrm{G})$. Ovariectomy was performed two weeks before the beginning of the experiment and all gilts were considered prepubertal due to the absence of corpora lutea and or corpora albicantia. Treatments were prepared by dissolving genistein (G-6055; LC Laboratories, Wobrun, MA) in dimethyl sulfoxide (DMSO). Treatments were administered by intramuscular (i.m.) injection daily at 1100 on day 0 and continuing through day 3 . Each pig received its assigned treatment: genistein treated pigs were administered $800 \mathrm{mg}$ of $99 \%$ pure form genistein dissolved in DMSO while the control group received equal amounts of DMSO. Pigs were fed $2 \mathrm{~kg}$ of a corn/soybean meal diet containing $17.3 \%$ crude protein, $1.1 \%$ lysine, and $3.1 \mathrm{Mcal} \mathrm{ME} / \mathrm{kg}$. Blood was collected via jugular venipuncture on day $0,1,2$, and 3 . Blood samples were allowed to clot overnight at $4^{\circ} \mathrm{C}$, then serum was collected by centrifugation $(1500 \mathrm{x} g$ for $30 \mathrm{~min}$ at $4^{\circ} \mathrm{C}$ ) and stored at $-20^{\circ} \mathrm{C}$. Pigs were slaughtered on day 4 , when blood, anterior pituitary glands, and medial basal hypothalami (MBH) were collected. The MBH consisted of a block of tissue limited rostrally by the optic chiasm, caudally by the mammillary bodies, laterally $3 \mathrm{~mm}$ from the midline and dorsally $4 \mathrm{~mm}$ from the base of the hypothalamus. Anterior pituitary glands and MBH were sectioned mid-sagitally, wrapped in foil, frozen in liquid nitrogen, then stored at $-80^{\circ} \mathrm{C}$. All experimental procedures were approved by the South Dakota State University Animal Care and Use Committee.

\subsection{Hormone Assays}

Serum and anterior pituitary concentrations of IGF-I were determined in duplicate by RIA [8] [9] for all blood and anterior pituitary glands. One half of each anterior pituitary gland was homogenized in a $15 \mathrm{~mL}$ polypropylene tube with $1 \mathrm{~mL}$ of homogenization buffer (1\% cholic acid, $0.1 \%$ SDS, $200 \mu \mathrm{M}$ phenylmethylsulfonyl fluoride, $100 \mu \mathrm{M}$ EDTA, $1 \mu \mathrm{M}$ leupeptin, $1 \mu \mathrm{M}$ pepstatin). Anterior pituitaries were homogenized on ice with a T25 Ultra-Turrax tissue disperser (IKA Works, Wilmington, NC, USA) for $30 \mathrm{~s}$ at 20,500 rpm. Anterior pituitary homogenates were then diluted to $100 \mathrm{mg}$ of AP tissue/ml with homogenization buffer. Homogenates were centrifuged at $12,000 \times \mathrm{g}$ for $10 \mathrm{~min}$ at $4^{\circ} \mathrm{C}$ and the supernatant was removed and stored at $-20^{\circ} \mathrm{C}$. Protein content 
of the AP homogenates (1:10 dilution) was determined by the Bradford method using reagents provided by Bio$\mathrm{Rad}$ (Hercules, CA, USA). Insulin-like growth factor binding proteins (IGFBP) were removed from sera and anterior pituitary gland samples with a 1:17 ratio of sample to acidified ethanol (12.5\% 2 N HCL:87.5\% absolute ethanol) [10]. Extracted samples were centrifuged $\left(12,000 \mathrm{x} g\right.$ at $\left.4^{\circ} \mathrm{C}\right)$ to separate IGFBP. A portion of the supernatant from the extracted sample was removed and neutralized with $0.855 \mathrm{M}$ Tris base, incubated an additional $4 \mathrm{~h}$ at $4^{\circ} \mathrm{C}$ then centrifuged at $12,000 \mathrm{x} g$ at $4^{\circ} \mathrm{C}$ to remove any additional IGFBP. When samples of this extract, equivalent to the original serum or AP homogenate sample were subjected to Western ligand blot analysis and subsequent phosphorimagery, no detected binding of [125I] IGF-I to IGFBP was observed. Recombinant human IGF-I (GF-050; Austral Biological, San Ramon, CA) was used as the standard and radioiodinated antigen. Antisera UB2-495 (National Hormone and Peptide Program, NIDDK) was used at a dilution of 1:100,000. Sensitivity of the assay was $16.3 \mathrm{pg} /$ tube. Inter-assay coefficient of variation was $16.7 \%$. Intra-assay coefficient of variation was $7.0 \%$.

Anterior pituitary concentrations of LH were determined in triplicate by RIA [11]. Porcine LH (AFP3881A; National Hormone and Peptide Program, NIDDK) was used as the radioiodinated antigen and standard. Luteinizing hormone antiserum (AFP15103194; National Hormone and Peptide Program) was used at a dilution of 1:200,000. Anterior pituitary homogenates were diluted $1: 25,000$ in $0.01 \mathrm{M}$ PBS- $0.1 \%$ gelatin prior to assay. Sensitivity of the assay was $0.13 \mathrm{ng} /$ tube. Intra-assay coefficient of variation was $13.3 \%$.

\subsection{Reverse Transcriptase Polymerase Chain Reaction (PCR) and Real-Time PCR}

Total RNA was isolated from one half of each AP gland and MBH using TriReagent (TR118, Molecular Research Company, Cincinnati, OH). Purity of RNA was determined by measuring the $\mathrm{A}_{260} / \mathrm{A}_{280}$ ratio. The ratio of all samples ranged from 1.8 to 2.0. The integrity of RNA was confirmed by agarose gel electrophoresis. Samples were treated with DNase according to the manufacturer's protocol (TurboDNA-free kit, Applied Biosystems, Foster City, CA, USA).

Reverse transcriptase PCR was used to measure the abundance of each specific mRNA relative to the abundance of porcine $\beta$-actin in the total RNA isolated from AP and MBH tissue. Expression of $\beta$-actin did not differ between treatments. Two micrograms of total RNA was reverse transcribed using random hexamer primers (High Capacity cDNA Reverse Transcription Kit, Applied Biosystems, Foster City, CA) to produce cDNA. One hundred micrograms of cDNA was used in each reaction. Twenty-five-microliter PCR reactions were performed using RT ${ }^{2}$ SYBR Green/ROX qPCR Master Mix (SuperArray Bioscience Corp., Foster City, CA). Primer pairs used for specific amplification of porcine IGF-I, IGF-I-type-1 receptor (IGF-IR), IGFBP-2, -3, and -5, LHßsubunit, GnRH receptor (GnRHR), kisspeptin, kisspeptin receptor and $\beta$-actin are listed in Table 1.

Reactions were measured using the Stratagene MX3000P quantitative real-time PCR instrument (Agilent Technologies, Foster City, CA) using thermal cycling conditions recommended by the manufacturer (40 cycles of $30 \mathrm{sec}$ at $95^{\circ} \mathrm{C}, 1 \mathrm{~min}$ at $55^{\circ} \mathrm{C}$ and $1 \mathrm{~min}$ at $72^{\circ} \mathrm{C}$ ). Concentrations of forward and reverse primers used for the genes of interest were $300 \mathrm{nM}$, except KISS1R, in which concentrations of forward and reverse primers were used at $800 \mathrm{nM}$ due to its low abundance. A linear response was obtained when these concentrations of primer pairs were used with increasing amounts of cDNA. Dissociation curve analysis was performed after each real time PCR run and confirmed that a single amplicon of appropriate melting temperature was present. Additionally, all amplicons were electrophoresed through a $2 \%$ agarose gel and stained with ethidium bromide to visualize that only amplicons of the appropriate size were present in each sample.

\subsection{Statistical Analysis}

To determine the effect of genistein on serum and AP concentrations of IGF-I and LH, statistical analyses were performed using the Proc Mixed procedure of JMP 8.0 model of SAS. The model for determining differences in serum concentrations of IGF-I was $Y_{i j k l}=\mu+$ Pig $_{i}+$ Treatment $_{j}+$ Pig $_{i}\left(\right.$ Treatment $_{j}+$ Day $_{k}+$ Treatment $_{j} \times$ Day $_{k}$ $+\operatorname{Pig}_{\mathrm{i}}(\text { Treatment })_{\mathrm{j}} \times$ Day $_{\mathrm{k}}$. Pig within treatment by date was the subplot error term used to test pig, day, and treatment by day effects. The model to determine the effect of genistein on AP concentrations of IGF-I and LH was $Y_{i}=\mu+$ Treatment $_{\mathrm{i}}$. The residual error term was used to test the effect of treatment.

Fold differences in expression of AP IGF-I, IGF-type-I receptor, IGFBP-2, IGFBP-3, IGFBP-5, GnRH receptor, $\mathrm{LH} \beta$, and MBH KISS1, and KISS1R between treatments were determined using the relative expression software tool [12]. 
Table 1. Primer sequences and corresponding cDNA fragements.

\begin{tabular}{|c|c|c|}
\hline Gene and Accession Number & Primer & Amplicon Size \\
\hline \multicolumn{3}{|l|}{ IGF-I (NM_214256.1) $)^{\mathrm{a}}$} \\
\hline Forward & 5'-ATGCCCAAGGCTCAGAAGGAAGTA-3' & $146 \mathrm{bp}$ \\
\hline Reverse & 5'-AGGTAACTCGTGCAGAGCAAAGGA-3' & \\
\hline \multicolumn{3}{|l|}{ IGF-type-1 R (NM_214172.1) ${ }^{\mathrm{b}}$} \\
\hline Forward & 5'-CCAGGCCAAAACGACATATGA-3' & $105 \mathrm{bp}$ \\
\hline Reverse & 5'-GTGGAAGACGTACAACATTATAACCAA-3' & \\
\hline \multicolumn{3}{|l|}{ pIGFBP2 (AF120326.1) ${ }^{\mathrm{c}}$} \\
\hline Forward & 5'-CGAGCAGGTTGCAGACAATG-3' & $142 \mathrm{bp}$ \\
\hline Reverse & 5'-GAACACAGCCAGCTCCTTCAT-3' & \\
\hline \multicolumn{3}{|l|}{ pIGFBP3 (AF085482.1) ${ }^{\mathrm{d}}$} \\
\hline Forward & 5'-CATCCACATCCCCAACTG-3' & $54 \mathrm{bp}$ \\
\hline Reverse & 5'-CGGCACTGCTTTTTCTTGTAGAA-3' & \\
\hline \multicolumn{3}{|l|}{ pIGFBP5 $(\mathrm{U} 41340.2)^{\mathrm{e}}$} \\
\hline Forward & 5'-CGCAAGGGATTCTACAAGAGAAA-3' & 74 bp \\
\hline Reverse & 5'-TCCACGCACCAGCAGATG-3' & \\
\hline \multicolumn{3}{|l|}{ GnRHR (NM_214273.1) } \\
\hline Forward & 5'-AGCCAACCTGTTGGAGACTCTGAT-3' & $101 \mathrm{bp}$ \\
\hline Reverse & 5'-AGCTGAGGACTTTGCAGAGGAACT-3' & \\
\hline \multicolumn{3}{|l|}{ LH $\beta$ (NM_214080.1) $)^{\mathrm{g}}$} \\
\hline Forward & 5'-ATGCTCCAGAGACTGCTGTTGT-3' & $151 \mathrm{bp}$ \\
\hline Reverse & 5'-TGCTGGTGGTAAAGGTGATGCAGA-3' & \\
\hline \multicolumn{3}{|l|}{$\mathrm{pER} \alpha\left(\mathrm{NM} \_214220\right)^{\mathrm{h}}$} \\
\hline Forward & 5'-GAATGTTGAAGCACAAGCGCCAGA-3' & $91 \mathrm{bp}$ \\
\hline Reverse & 5'-ACCGGGCTGTTCTTCTTAGTGTGT-3' & \\
\hline \multicolumn{3}{|l|}{ pKISS1 (NM_0013464.1) $)^{\mathrm{i}}$} \\
\hline Forward & 5'-GGCAGCTGAGTTCTTTCTTTG-3' & 89 bp \\
\hline Reverse & 5'-CGGGCCTGTAGATCTAGGATT-3' & \\
\hline \multicolumn{3}{|l|}{ pKISS1R (NM_001044624.2) $)^{j}$} \\
\hline Forward & 5'-CAGGGAACTCACTTGTGATCTT-3' & $110 \mathrm{bp}$ \\
\hline Reverse & 5'-GCACAGCAGAAACGTCAAATC-3' & \\
\hline \multicolumn{3}{|l|}{$\mathrm{p} \beta$-actin $(\mathrm{U} 07786.1)^{\mathrm{k}}$} \\
\hline Forward & 5'-TCGCCGACAGGATGCAGAAGGA-3' & $129 \mathrm{bp}$ \\
\hline Reverse & 5'-AGGTGGACAGCGAGGCCAGGAT-3' & \\
\hline
\end{tabular}




\section{Results}

\section{Serum, AP Hormone, and Gene Expression}

Serum concentrations of IGF-I were determined on each of the four days of genistein administration. Mean serum concentrations of IGF-I did not differ $(P>0.05)$ between $\mathrm{G}$ pigs and $\mathrm{C}$ pigs from days 0 through 4 (Figure 1). Likewise, mean AP concentrations of IGF-I did not differ $(P>0.05)$ between $\mathrm{G}$ pigs and $\mathrm{C}$ pigs (Figure 2(a)). However, mean AP concentrations of LH were greater $(P<0.05)$ in $\mathrm{G}$ pigs than $\mathrm{C}$ pigs (Figure 2(b)).

Relative expression of components of the AP IGF system changed with genistein treatment. Mean relative expression of AP IGF-I was 1.2 fold greater $(P<0.01)$ in G pigs than C pigs (Figure 3(a)). Mean relative expression of AP IGF-I receptor did not differ $(P>0.05)$ between $\mathrm{G}$ pig and $\mathrm{C}$ pigs (Figure 3(b)). Mean relative expression of AP IGFBP-2 and -3 were each not different $(P>0.05)$ between $\mathrm{G}$ pigs and $\mathrm{C}$ pigs (Figure 4(a) and Figure 4(b)), however, mean relative expression of AP IGFBP-5 was 1.6 fold greater $(P<0.01)$ in G pigs than in C pigs (Figure 4(c)).

Relative expression of $\mathrm{GnRH}$ receptor, but not $\mathrm{LH} \beta$ was influenced by genistein. Mean relative expression of AP GnRH receptor was 1.4 fold greater $(P<0.01)$ in $\mathrm{G}$ pigs compared to $\mathrm{C}$ pigs (Figure $5(\mathrm{a})$ ). No difference was detected $(P>0.05)$ in mean relative expression of AP LH $\beta$ subunit between $\mathrm{G}$ pigs and $\mathrm{C}$ pigs (Figure 5(b)).

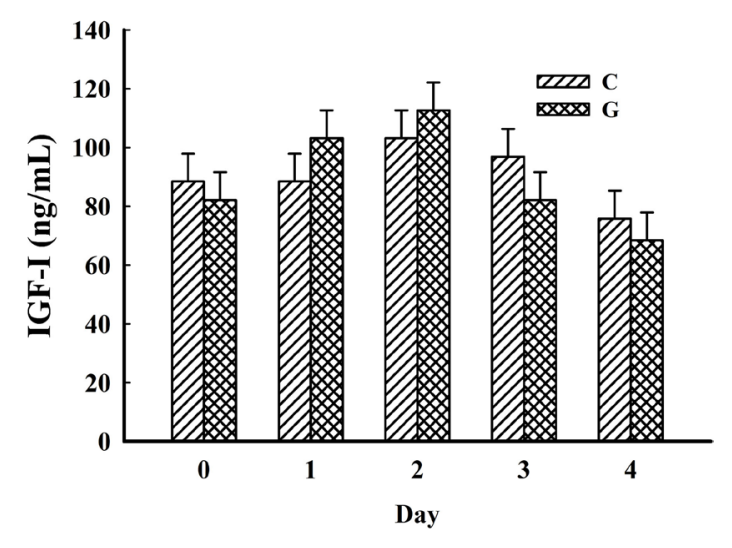

Figure 1. Mean serum concentrations of IGF-I on days 0 through 4 in control pigs $(\mathrm{C} ; \mathrm{n}=8)$, and genistein treated pigs $(\mathrm{G} ; \mathrm{n}=8 ; 800 \mathrm{mg}$ genistein) administered i.m. treatments daily from day 0 through day 4 . Means are expressed as least-square means \pm SEM.

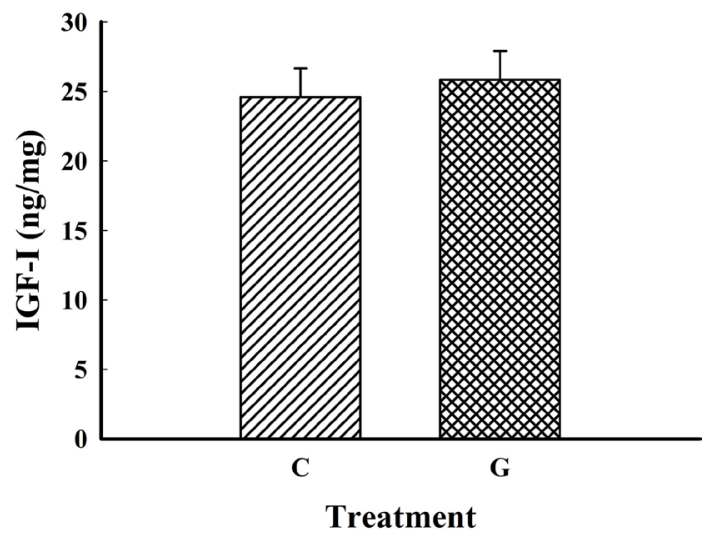

(a)

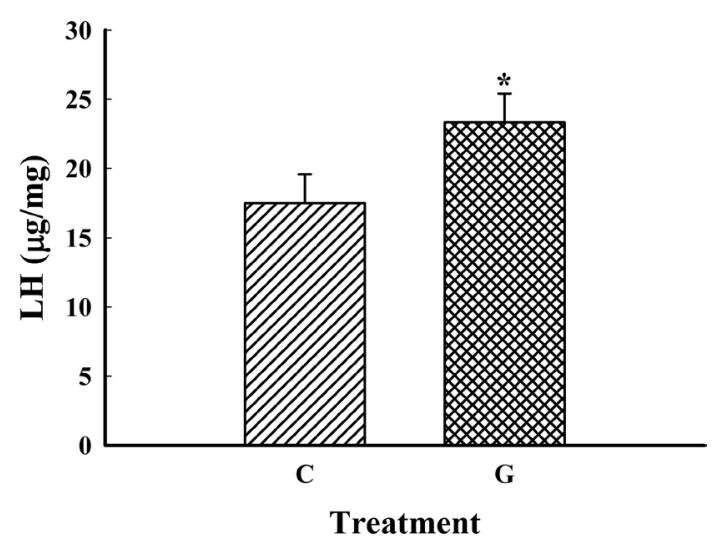

(b)

Figure 2. Mean anterior pituitary concentrations of IGF-I (a) and LH (b) on d 4 in control pigs $(\mathrm{C} ; \mathrm{n}=8)$ and genistein treated pigs $(\mathrm{G} ; \mathrm{n}=8 ; 800 \mathrm{mg}$ genistein) administered i.m. treatments daily from day 0 through day 4 . Means are expressed as least-square means \pm SEM. *Mean differs from control pigs $(P<0.05)$. 


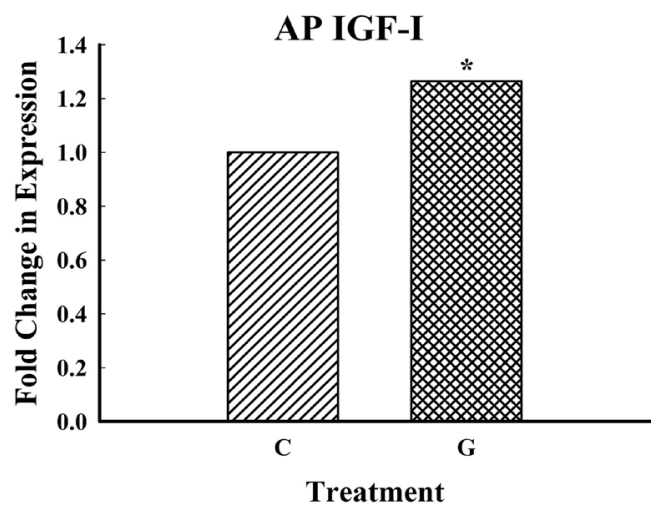

(a)

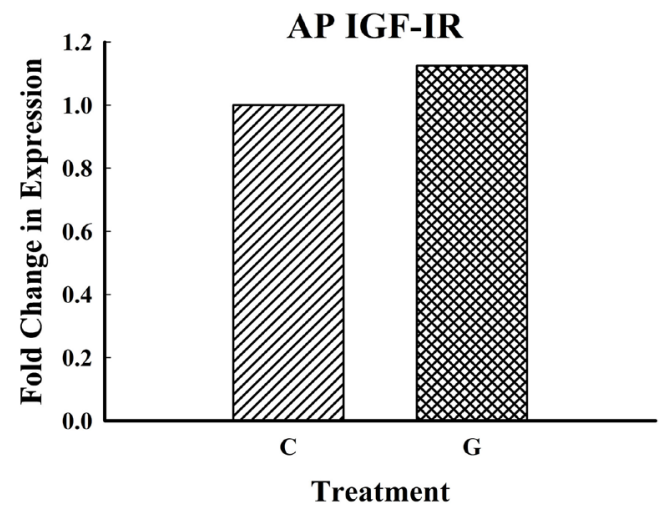

(b)

Figure 3. Mean relative expression of anterior pituitary IGF-I (a) and IGF-I receptor (b) on d 4 in control pigs $(C ; n=8)$ and genistein treated pigs $(\mathrm{G} ; \mathrm{n}=8 ; 800 \mathrm{mg}$ genistein) administered i.m. treatments daily from day 0 through day 4 . Total RNA was DNase treated and analyzed for the level of porcine IGF-I and IGF-I receptor by quantitative RT-PCR with normalization for the corresponding level of porcine $\beta$-actin. *Mean differs $(P<0.01)$ from controls as determined by the relative expression software tool.

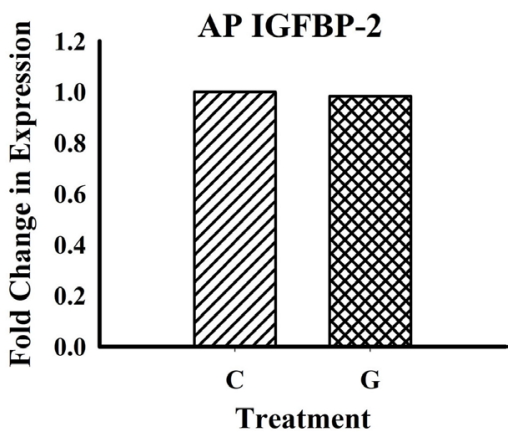

(a)

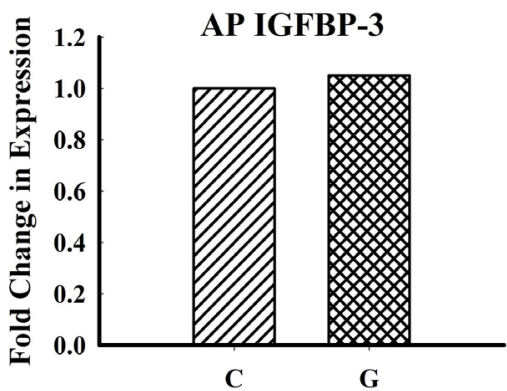

Treatment

(b)

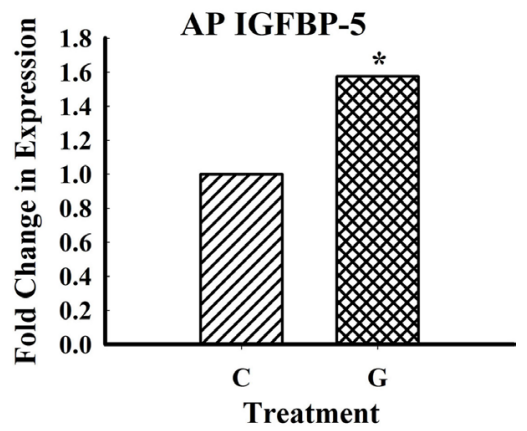

(c)

Figure 4. Mean relative expression of anterior pituitary IGFBP-2 (a) IGFBP-3 (b) and IGFBP-5 (c) on d 4 in control pigs $(C ; n=8)$ and genistein treated pigs $(G ; n=8 ; 800 \mathrm{mg}$ genistein) administered i.m. treatments daily from day 0 through day 4. Total RNA was DNase treated and analyzed for the level of porcine IGFBP-2, IGFBP-3, and IGFBP-5 by quantitative RT-PCR with normalization for the corresponding level of porcine $\beta$-actin. *Mean differs $(P<0.01)$ from controls as determined by the relative expression software tool.

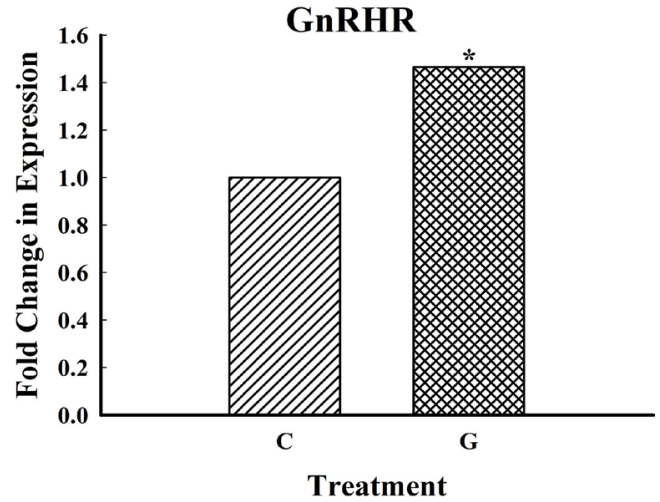

(a)

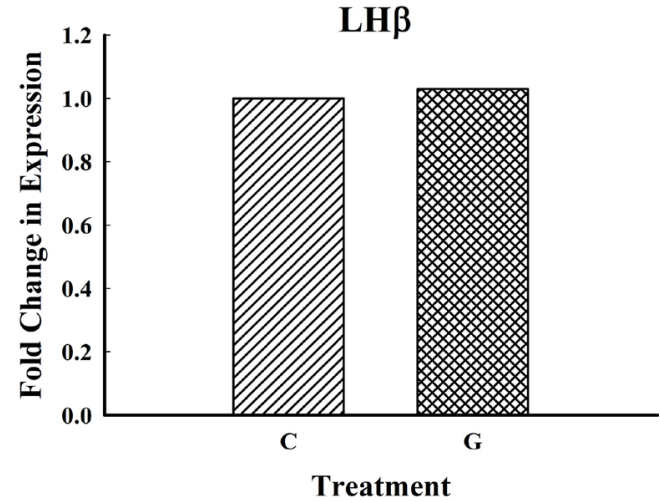

(b)

Figure 5. Mean relative expression of anterior pituitary GnRHR (a) and LH $\beta$ subunit (b) on $\mathrm{d} 4$ in control pigs $(\mathrm{C} ; \mathrm{n}=8)$ and genistein treated pigs $(\mathrm{G} ; \mathrm{n}=8 ; 800 \mathrm{mg}$ genistein) administered i.m. treatments daily from day 0 through day 4 . Total RNA was DNase treated and analyzed for the level of porcine GnRHR and LH $\beta$ subunit by quantitative RT-PCR with normalization for the corresponding level of porcine $\beta$-actin. *Mean differs $(P<0.01)$ from controls as determined by the relative expression software tool. 
Relative expression of kisspeptin, but not the kisspeptin receptor, was decreased by the administration of genistein. Mean relative expression of KISS1 in the MBH was reduced $(P<0.001)$ in G pigs compared to C pigs (Figure 6(a)). Mean relative expression of KISS1R was not different $(P>0.05)$ between $\mathrm{G}$ pigs and $\mathrm{C}$ pigs (Figure 6(b)).

\section{Discussion}

Genistein, a bioactive isoflavone, is structurally similar to estradiol [13] and has been shown to have estrogenic activities in numerous species [3] [14]-[16]. Genistein has the ability to bind to estrogen receptors and compete with estradiol for binding to the estrogen receptors [13]. Chen and Wong [17] administered genistein to MCF-7 breast cancer cells, and determined that genistein caused an induction of the IGF-I signaling pathway, similar to estradiol. Genistein has the ability to affect numerous reproductive processes, including stimulation of IGF-I release from bovine and porcine granulosa cells, and estradiol release from porcine ovarian follicles [4]. It has been demonstrated that serum concentrations of IGF-I increase with circulating levels of estradiol-17 $\beta$ in pigs [18], sheep [11], and cattle [19]. Rempel and Clapper [18] also determined that administration of estradiol to barrows increased anterior pituitary concentrations of IGF-I.

In the current study, genistein was administered to ovariectomized gilts at $800 \mathrm{mg} /$ day for a short period of time (4 days), but serum and AP concentrations of IGF-I did not increase. The amount of genistein used in the present experiment was two-fold as much as that used by Clapper and Tomlin [5], but was administered for a shorter length of time. Clapper and Tomlin [5] injected barrows with $400 \mathrm{mg}$ genistein daily for 16 days and found it increased anterior pituitary concentrations of IGF-I, however, serum concentrations of IGF-I were not different than controls. Farmer et al. [20] injected sows with an equivalent amount of genistein and found no change in serum concentrations of IGF-I. Thus, the gilts in the present study may not have been treated with genistein long enough to increase AP or serum IGF-I or the effects of genistein on the IGF system in the pig are tissue specific.

In the present study, genistein increased expression of IGF-I in the anterior pituitary. Low concentrations of genistein also increased mRNA expression of IGF-I in human uterine leiomyoma cells [21]. Kalbe et al. [22] found contradicting results in porcine skeletal muscle cells cultures. In proliferating and differentiating porcine skeletal muscle cultures low concentrations of genistein caused no increase in expression of IGF-I, while high doses of genistein caused reduced expression of IGF-I [22]. Even though AP expression of IGF-I increased there was not a corresponding increase in the protein. Perhaps the short duration of the experiment did not provide sufficient time for the translation of the mRNA into protein.

Anterior pituitary expression of IGF-I-type-1 receptor did not increase in the present study in response to short term administration of genistein. Genistein at high concentrations reduced expression of the IGF-I type 1 receptor in cultured porcine skeletal muscle fibers [22]. High concentrations of genistein also inhibited MCF-7 cell proliferation, while low concentrations of genistein stimulated MCF-7 cell proliferation [17]. Chen and Wong [17]

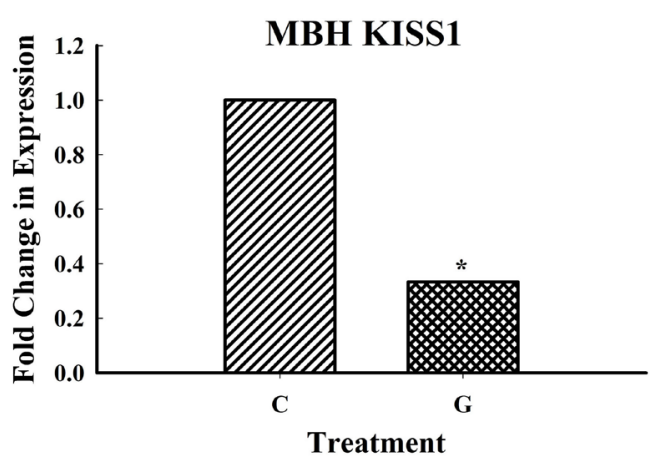

(a)

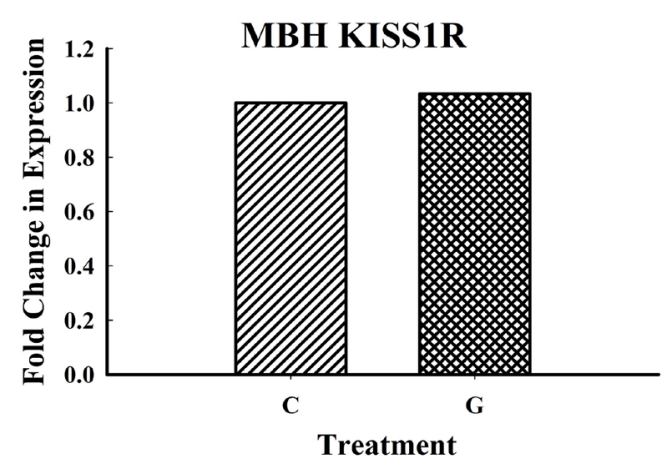

(b)

Figure 6. Mean relative expression of medial basal hypothalamic KISS1 (a) KISS1 receptor (b) and ER $\alpha$ (C) on d 4 in control pigs $(\mathrm{C} ; \mathrm{n}=8)$ and genistein treated pigs $(\mathrm{G} ; \mathrm{n}=8 ; 800 \mathrm{mg}$ genistein) administered i.m. treatments daily from day 0 through day 4. Total RNA was DNase treated and analyzed for the level of porcine KISS1, KISS1R, and ER $\alpha$ by quantitative RT-PCR with normalization for the corresponding level of porcine $\beta$-actin. *Mean differs $(P<0.001)$ from controls as determined by the relative expression software tool. 
concluded that low doses of genistein increased both protein and mRNA expression of the IGF-I-type-1 receptor and increased the IGF-I receptor promoter activity in MCF-7 cells. Chen et al. [23] also established that the increase in expression of IGF-I type 1 receptor by genistein was dependent upon association of the estrogen receptor and the IGF-I type 1 receptor. Genistein has greater affinity for ER $\beta$ compared to ER $\alpha$ [1] and the anterior pituitary gland has greater amounts of $\operatorname{ER} \alpha$ than $\operatorname{ER} \beta[1]$. Because genistein has higher affinity for the $\operatorname{ER} \beta$ genistein may not have interacted with the estrogen receptor in the anterior pituitary to the extent required to increase expression of AP IGF-I-type-1 receptor in the present study.

Relative amounts and expression of IGFBP have been shown to be modulated by estrogens in a number of species, including the pig. Insulin-like growth factor binding protein-5 is known as a potentiator of IGF-I activity, allowing IGF-I to be more available to its receptor [24]. Clapper and Taylor [25] determined that on day 19 of the porcine estrous cycle, relative amounts of IGFBP-5 increased with a concomitant increase in estradiol, implying IGFBP-5 maybe regulated by estradiol. In the bovine, it has also been determined that changes in anterior pituitary IGFBP-5 were correlated with changes in serum levels of estradiol during the estrous cycle [9]. Others have demonstrated that expression of IGFBP-5 to estrogens may be tissue specific. Insulin-like growth factor binding protein-5 expression was down-regulated when estrogen positive ovarian cancer cells were treated with estradiol [26]. However, bovine granulosa and theca cell expression of IGFBP-5 did not change with estradiol treatment [27]. A study comparing estrogen response genes in ovariectomized adult mice determined IGFBP-5 expression was increased in the vagina and not in the uterus or mammary gland after estrogen exposure [28]. In the current study, anterior pituitary expression of IGFBP-5 increased with short term administration of genistein. Genistein appears to have enough estrogenic activity to increase expression of AP IGFBP-5 in ovariectomized gilts which may make IGF-I more readily available to its receptor. The fact that expression of AP IGFBP-2 and -3 did not change with administration of genistein may be due to its estrogenic potency in comparison with estradiol, or the length of time it was administered. When expression or relative amounts of these two IGFBP changed in the AP as observed in the rat [29], ewe [11] or pig [18] [20] [30] it was in response to physiological levels of estradiol or administration of estradiol.

Anterior pituitary expression of GnRH receptor increased in ovariectomized gilts following short term administration of genistein. Genistein's ability to increase expression of GnRH receptors may have been directly due to its estrogenic effect [1]. Genistein may have also been working indirectly by influencing the release of $\mathrm{GnRH}$. In the absence of progesterone, estradiol can increase the secretion of GnRH in the ewe [31] and GnRH can stimulate expression of its own receptor [32]-[34]. If genistein, through its estrogenic activity, was capable of increasing $\mathrm{GnRH}$, this may have resulted in greater expression of GnRH receptors. Genistein's ability to increase the expression of GnRH receptors may play an important role during various phases of the estrous cycle by increasing sensitivity of the anterior pituitary to GnRH in much the same fashion as estradiol [35].

Anterior pituitary concentrations of LH increased with short term administration of genistein in this study. Intracerebroventricular infusion of genistein to ovariectomized ewes caused an increase in LH-immunoreactive cells in the pituitary, and also an increase in serum concentrations of LH [36]. In this latter study, it was speculated that genistein inhibited the tonic secretion of LH and caused a large release of LH like that of the preovulatory surge. However, in the present study, blood samples were not taken at frequent enough intervals to adequately characterize serum concentrations of LH. When Norrby et al. [37] treated gilts with approximately 300 $\mathrm{mg}$ of genistein daily for three days, serum concentrations of LH were reduced in genistein treated gilts versus controls. The ability of genistein to increase anterior pituitary LH was presumably due to areduction in LH release. This is further supported by the fact that expression of $\mathrm{LH} \beta$ subunit was not increased by administration of genistein. Genistein may also have increased AP LH levels by increasing GnRH receptors and inhibiting the tonic release of LH [38].

Anterior pituitary expression of the $\mathrm{LH} \beta$ subunit did not increase with short term administration of genistein in this study. However, ovariectomized ewes treated with an intracerebroventricular infusion of genistein experienced increased mRNA expression of LH $\beta$ in pituitary cells [36] [39]. In the current study, short term administration of genistein did not increase the $\mathrm{LH} \beta$ subunit level in ovariectomized gilts. The administration technique may account for the lack of change in expression of $\mathrm{LH} \beta$ in the present study. Intracerebroventricular infusion of genistein allows direct contact with the brain, which may account for the increased expression of LH $\beta$ subunit in the AP. Previous studies indicated an increase in LH $\beta$ expression after genistein treatment, which may be interpreted as a rapid synthesis and release of LH [39]. However, in this study, the lack of an increase in expression of $\mathrm{LH} \beta$ may indicate genistein had no affect or was not delivered in a manner to cause a dramatic increase in 
synthesis and release of LH.

Kisspeptin, a peptide product of the KISS1 gene, increases peripheral gonadotropin secretion when administered centrally or peripherally in a number of species, including the pig [40]. Kisspeptin neurons express steroid receptors [41] and it has been shown that gonadectomy increases kisspeptin expression in the arcuate nucleus of mice and rats while steroid replacement reduces this expression [42] [43]. The release of hypothalamic and hypophyseal hormones is controlled by negative and positive feedback of gonadal steroids, with estradiol playing a key role in both kinds of feedback. Kisspeptin-expressing neurons have been found to be distributed in the periventricular nucleus and arcuate nucleus of the pig [44]. Tomikawa et al. [44] also reported that KISS1-expressing cells were decreased in the arcuate nucleus of ovariectomized pigs treated with estradiol benzoate. In the present experiment expression of KISS1 was decreased in the MBH of genistein treated gilts, an area containing both the periventricular and arcuate nuclei. Thus, the findings presented here suggest genistein influences KISS1 in the hypothalamus, however, detection of precise hypothalamic nuclei which may be involved was beyond the scope of our experiment. Whether genistein can modulate GnRH/LH secretion in the pig through kisspeptin neurons requires further investigation.

\section{Conclusion}

In conclusion, short term administration of genistein to ovariectomized gilts increased expression of components of the AP IGF-I system and GnRH receptors which could modulate gonadotropin synthesis or release. However, genistein may be acting at the level of the hypothalamus to decrease GnRH release by reducing kisspeptin synthesis. Whether genistein increases or decreases gonadotropin secretion or synthesis remains to be determined and will depend upon the sum total of the positive and negative influences.

\section{References}

[1] Kuiper, G.G., Lemmen, J.G., Carlsson, B., Corton, J.C., Safe, S.H., van der Saag, P.T., van der Burg, B. and Gustafsson, J.A. (1998) Interaction of Estrogenic Chemicals and Phytoestrogens with Estrogen Receptor Beta. Endocrinology, 139, 4252-4263. http://dx.doi.org/10.1210/endo.139.10.6216

[2] Allred, C.D., Ju, Y.H., Allred, K.F., Chang, J. and Helferich, W.G. (2001) Dietary Genistin Stimulates Growth of Estrogen-Dependent Breast Cancer Tumors Similar to That Observed with Genistein. Carcinogenesis, 22, 1667-1673. http://dx.doi.org/10.1093/carcin/22.10.1667

[3] Ford, J.A., Clark, S.G., Walters, E.M., Wheeler, M.B. and Hurley, W.L. (2006) Estrogenic Effects of Genistein on Reproductive Tissues of Ovariectomized Gilts. Journal of Animal Science, 84, 834-842.

[4] Makarevich, A., Sirotkin, A., Taradajnik, T. and Chrenek, P. (1997) Effects of Genistein and Lavendustin on Reproductive Processes in Domestic Animals in Vitro. Journal of Steroid Biochemistry and Molecular Biology, 63, 329-337. http://dx.doi.org/10.1016/S0960-0760(97)00092-7

[5] Clapper, J. and Tomlin, A. (2012) Effects of the Phytoestrogen Genistein on the Porcine Anterior Pituitary Insulin-Like Growth Factor System. Domestic Animal Endocrinology, 42, 173-182. http://dx.doi.org/10.1016/j.domaniend.2011.11.007

[6] Hashizume, T., Kumahara, A., Fujino, M. and Okada, K. (2002) Insulin-Like Growth Factor I Enhances Gonadotropinreleasing Hormone-Stimulated Luteinizing Hormone Release from Bovine Anterior Pituitary Cells. Animal Reproduction Science, 70, 13-21. http://dx.doi.org/10.1016/S0378-4320(01)00190-7

[7] Whitley, N.C., Barb, C.R., Utley, R.V., Popwell, J.M., Kraeling, R.R. and Rampacek, G.B. (1995) Influence of Stage of the Estrous Cycle on Insulin-Like Growth Factor-I Modulation of Luteinizing Hormone Secretion in the Gilt. Biology of Reproduction, 53, 1359-1364. http://dx.doi.org/10.1095/biolreprod53.6.1359

[8] Echternkamp, S.E., Spicer, L.J., Gregory, K.E., Canning, S.F. and Hammond, J.M. (1990) Concentrations of InsulinLike Growth Factor-I in Blood and Ovarian Follicular Fluid of Cattle Selected for Twins. Biology of Reproduction, 43, 8-14. http://dx.doi.org/10.1095/biolreprod43.1.8

[9] Funston, R.N., Moss, G.E. and Roberts, A.J. (1995) Insulin-Like Growth Factor-I (IGF-I) and IGF-Binding Proteins in Bovine Sera and Pituitaries at Different Stages of the Estrous Cycle. Endocrinology, 136, 62-68.

[10] Daughaday, W.H., Mariz, I.K. and Blethen, S.L. (1980) Inhibition of Access of Bound Somatomedin to Membrane Receptor and Immunobinding Sites: a Comparison of Radioreceptor and Radioimmunoassay of Somatomedin in Native and Acid-Ethanol-Extracted Serum. Journal of Clinical Endocrinology and Metabolism, 51, 781-788. http://dx.doi.org/10.1210/jcem-51-4-781

[11] Clapper, J.A., Snyder, J.L., Roberts, A.J., Hamernik, D.L. and Moss, G.E. (1998) Estradiol Increases Relative Amounts 
of Insulin-Like Growth Factor Binding Protein (IGFBP)-3 in Serum and Expression of IGFBP-2 in Anterior Pituitaries of Ewes. Biology of Reproduction, 59, 124-130. http://dx.doi.org/10.1095/biolreprod59.1.124

[12] Pfaffl, M.W., Horgan, G.W. and Dempfle, L. (2002) Relative Expression Software Tool (REST()) for Group-Wise Comparison and Statistical Analysis of Relative Expression Results in Real-Time PCR. Nucleic Acids Research, 30, e36. http://dx.doi.org/10.1093/nar/30.9.e36

[13] Bhathena, S.J. and Velasquez, M.T. (2002) Beneficial Role of Dietary Phytoestrogens in Obesity and Diabetes. American Journal of Clinical Nutrition, 76, 1191-1201.

[14] Ciereszko, R., Opalka, M., Kaminska, B., Gorska, T. and Dusza, L. (2003) Prolactin Signalling in Porcine Theca Cells: The Involvement of Protein Kinases and Phosphatases. Reproduction, Fertility and Development, 15, 27-35. http://dx.doi.org/10.1071/RD02049

[15] Gorski, K., Gajewska, A., Romanowicz, K. and Misztal, T. (2007) Genistein-Induced Pituitary Prolactin Gene Expression and Prolactin Release in Ovariectomized Ewes Following a Series of Intracerebroventricular Infusions. Reproductive Biology, 7, 233-246.

[16] Wood, C.E., Appt, S.E., Clarkson, T.B., Franke, A.A., Lees, C.J., Doerge, D.R. and Cline, J.M. (2006) Effects of HighDose Soy Isoflavones and Equol on Reproductive Tissues in Female Cynomolgus Monkeys. Biology of Reproduction, 75, 477-486. http://dx.doi.org/10.1095/biolreprod.106.052142

[17] Chen, W.F. and Wong, M.S. (2004) Genistein Enhances Insulin-Like Growth Factor Signaling Pathway in Human Breast Cancer (MCF-7) Cells. Journal of Clinical Endocrinology and Metabolism, 89, 2351-2359. http://dx.doi.org/10.1210/jc.2003-032065

[18] Rempel, L.A. and Clapper, J.A. (2002) Administration of Estradiol-17 $\beta$ Increases Anterior Pituitary IGF-I and Relative Amounts of Serum and Anterior Pituitary IGF-Binding Proteins in Barrows. Journal of Animal Science, 80, $214-224$.

[19] Hays, C.L., Davenport, G.M., Osborn, T.G. and Mulvaney, D.R. (1995) Effect of Dietary Protein and Estradiol-17 $\beta$ on Growth and Insulin-Like Growth Factor I in Cattle during Realimentation. Journal of Animal Science, 73, 589-597.

[20] Farmer, C., Robertson, P. and Gilani, G.S. (2013) Effects of Dose and Route of Administration of Genistein on Isoflavone Concentrations in Post-Weaned and Gestating Sows. Animal, 7, 983-989. http://dx.doi.org/10.1017/S1751731113000037

[21] Di, X., Yu, L., Moore, A.B., Castro, L., Zheng, X., Hermon, T. and Dixon, D. (2008) A Low Concentration of Genistein Induces Estrogen Receptor-Alpha and Insulin-Like Growth Factor-I Receptor Interactions and Proliferation in Uterine Leiomyoma Cells. Human Reproduction, 23, 1873-1883. http://dx.doi.org/10.1093/humrep/den087

[22] Kalbe, C., Mau, M. and Rehfeldt, C. (2008) Developmental Changes and the Impact of Isoflavones on mRNA Expression of IGF-I Receptor, EGF Receptor and Related Growth Factors in Porcine Skeletal Muscle Cell Cultures. Growth Hormone \& IGF Research, 18, 424-433. http://dx.doi.org/10.1016/j.ghir.2008.03.002

[23] Chen, Y.C., Nagpal, M.L., Stocco, D.M. and Lin, T. (2007) Effects of Genistein, Resveratrol, and Quercetin on Steroidogenesis and Proliferation of MA-10 Mouse Leydig Tumor Cells. Journal of Endocrinology, 192, 527-537. http://dx.doi.org/10.1677/JOE-06-0087

[24] Jones, J.I. and Clemmons, D.R. (1995) Insulin-Like Growth Factors and Their Binding Proteins: Biological Actions. Endocrine Reviews, 16, 3-34. http://dx.doi.org/10.1210/er.16.1.3

[25] Clapper, J. and Taylor, A. (2011) Components of the Porcine Anterior Pituitary Insulin-Like Growth Factor System throughout the Estrous Cycle. Domestic Animal Endocrinology, 40, 67-76. http://dx.doi.org/10.1016/j.domaniend.2010.09.001

[26] Walker, G., MacLeod, K., Williams, A.R., Cameron, D.A., Smyth, J.F. and Langdon, S.P. (2007) Insulin-Like Growth Factor Binding Proteins IGFBP3, IGFBP4, and IGFBP5 Predict Endocrine Responsiveness in Patients with Ovarian Cancer. Clinical Cancer Research, 13, 1438-1444. http://dx.doi.org/10.1158/1078-0432.CCR-06-2245

[27] Voge, J.L., Santiago, C.A., Aad, P.Y., Goad, D.W., Malayer, J.R. and Spicer, L.J. (2004) Quantification of InsulinLike Growth Factor Binding Protein mRNA Using Real-Time PCR in Bovine Granulosa and Theca Cells: Effect of Estradiol, Insulin, and Gonadotropins. Domestic Animal Endocrinology, 26, 241-258. http://dx.doi.org/10.1016/j.domaniend.2003.11.002

[28] Suzuki, A., Urushitani, H., Watanabe, H., Sato, T., Iguchi, T., Kobayashi, T. and Ohta, Y. (2007) Comparison of Estrogen Responsive Genes in the Mouse Uterus, Vagina and Mammary Gland. Journal of Veterinary Medical Science, 69, 725-731. http://dx.doi.org/10.1292/jvms.69.725

[29] Michels, K.M., Lee, W.H., Seltzer, A., Saavedra, J.M. and Bondy, C.A. (1993) Up-Regulation of Pituitary [125I] InsulinLike Growth Factor-I (IGF-I) Binding and IGF Binding Protein-2 and IGF-I Gene Expression by Estrogen. Endocrinology, 132, 23-29. http://dx.doi.org/10.1210/en.132.1.23

[30] Hilleson-Gayne, C.K. and Clapper, J.A. (2005) Effects of Decreased Estradiol-17 $\beta$ on the Serum and Anterior Pituitary IGF-I System in Pigs. Journal of Endocrinology, 187, 369-378. http://dx.doi.org/10.1677/joe.1.06253 
[31] Moenter, S.M., Caraty, A. and Karsch, F.J. (1990) The Estradiol-Induced Surge of Gonadotropin-Releasing Hormone in the Ewe. Endocrinology, 127, 1375-1384. http://dx.doi.org/10.1210/endo-127-3-1375

[32] Khalid, M., Haresign, W. and Hunter, M.G. (1987) Pulsatile GnRH Administration Stimulates the Number of Pituitary GnRH Receptors in Seasonally Anoestrous Ewes. Journal of Reproduction and Fertility, 79, 223-230. http://dx.doi.org/10.1530/jrf.0.0790223

[33] Nett, T.M., Crowder, M.E., Moss, G.E. and Duello, T.M. (1981) GnRH-Receptor Interaction. V. Down-Regulation of Pituitary Receptors for GnRH in Ovariectomized Ewes by Infusion of Homologous Hormone. Biology of Reproduction, 24, 1145-1155.

[34] Turzillo, A.M., DiGregorio, G.B. and Nett, T.M. (1995) Messenger Ribonucleic Acid for Gonadotropin-Releasing Hormone Receptor and Numbers of Gonadotropin-Releasing Hormone Receptors in Ovariectomized Ewes after Hypothalamic-Pituitary Disconnection and Treatment with Estradiol. Journal of Animal Science, 73, 1784-1788.

[35] Turzillo, A.M., Clapper, J.A., Moss, G.E. and Nett, T.M. (1998) Regulation of Ovine GnRH Receptor Gene Expression by Progesterone and Oestradiol. Journal of Reproduction and Fertility, 113, 251-256. http://dx.doi.org/10.1530/jrf.0.1130251

[36] Wojcik-Gladysz, A., Romanowicz, K., Misztal, T., Polkowska, J. and Barcikowski, B. (2005) Effects of Intracerebroventricular Infusion of Genistein on the Secretory Activity of the GnRH/LH Axis in Ovariectomized Ewes. Animal Reproduction Science, 86, 221-235. http://dx.doi.org/10.1016/j.anireprosci.2004.08.004

[37] Norrby, M., Madsen, M., Saravia, F., Lundeheim, N. and Madej, A. (2011) Genistein Alters the Release of Oxytocin, Prostaglandins, Cortisol and LH during Insemination in Gilts. Reproduction in Domestic Animals, 46, 316-324. http://dx.doi.org/10.1111/j.1439-0531.2010.01669.x

[38] Caraty, A., Locatelli, A. and Martin, G.B. (1989) Biphasic Response in the Secretion of Gonadotrophin-Releasing Hormone in Ovariectomized Ewes Injected with Oestradiol. Journal of Endocrinology, 123, 375-382. http://dx.doi.org/10.1677/joe.0.1230375

[39] Polkowska, J., Ridderstrale, Y., Wankowska, M., Romanowicz, K., Misztal, T. and Madej, A. (2004) Effects of Intracerebroventricular Infusion of Genistein on Gonadotrophin Subunit mRNA and Immunoreactivity of Gonadotrophins and Oestrogen Receptor-Alpha in the Pituitary Cells of the Anoestrous Ewe. Journal of Chemical Neuroanatomy, 28, 217-224. http://dx.doi.org/10.1016/i.jchemneu.2004.07.004

[40] Lents, C.A., Heidorn, N.L., Barb, C.R. and Ford, J.J. (2008) Central and Peripheral Administration of Kisspeptin Activates Gonadotropin but Not Somatotropin Secretion in Prepubertal Gilts. Reproduction, 135, 879-887. http://dx.doi.org/10.1530/REP-07-0502

[41] Estrada, K.M., Clay, C.M., Pompolo, S., Smith, J.T. and Clarke, I.J. (2006) Elevated KiSS-1 Expression in the Arcuate Nucleus Prior to the Cyclic Preovulatory Gonadotrophin-Releasing Hormone/Lutenising Hormone Surge in the Ewe Suggests a Stimulatory Role for Kisspeptin in Oestrogen-Positive Feedback. Journal of Neuroendocrinology, 18, 806809. http://dx.doi.org/10.1111/j.1365-2826.2006.01485.x

[42] Adachi, S., Yamada, S., Takatsu, Y., Matsui, H., Kinoshita, M., Takase, K., Sugiura, H., Ohtaki, T., Matsumoto, H., Uenoyama, Y., Tsukamura, H., Inoue, K. and Maeda, K. (2007) Involvement of Anteroventral Periventricular Metastin/Kisspeptin Neurons in Estrogen Positive Feedback Action on Luteinizing Hormone Release in Female Rats. Journal of Reproduction and Development, 53, 367-378. http://dx.doi.org/10.1262/jrd.18146

[43] Clarkson, J. and Herbison, A.E. (2006) Postnatal Development of Kisspeptin Neurons in Mouse Hypothalamus; Sexual Dimorphism and Projections to Gonadotropin-Releasing Hormone Neurons. Endocrinology, 147, 5817-5825. http://dx.doi.org/10.1210/en.2006-0787

[44] Tomikawa, J., Homma, T., Tajima, S., Shibata, T., Inamoto, Y., Takase, K., Inoue, N., Ohkura, S., Uenoyama, Y., Maeda, K. and Tsukamura, H. (2010) Molecular Characterization and Estrogen Regulation of Hypothalamic KISS1 Gene in the Pig. Biology of Reproduction, 82, 313-319. http://dx.doi.org/10.1095/biolreprod.109.079863 